\title{
The impact of historical land use change from 1850 to 2000 on secondary particulate matter and ozone
}

\author{
Colette L. Heald ${ }^{1}$ and Jeffrey A. Geddes ${ }^{2}$ \\ ${ }^{1}$ Department of Civil and Environmental Engineering, Massachusetts Institute of Technology, Cambridge, MA, USA \\ ${ }^{2}$ Department of Earth and Environment, Boston University, Boston, MA, USA \\ Correspondence to: Colette L. Heald (heald@ mit.edu)
}

Received: 1 September 2016 - Published in Atmos. Chem. Phys. Discuss.: 5 September 2016

Revised: 15 November 2016 - Accepted: 21 November 2016 - Published: 5 December 2016

\begin{abstract}
Anthropogenic land use change (LUC) since preindustrial (1850) has altered the vegetation distribution and density around the world. We use a global model (GEOSChem) to assess the attendant changes in surface air quality and the direct radiative forcing (DRF). We focus our analysis on secondary particulate matter and tropospheric ozone formation. The general trend of expansion of managed ecosystems (croplands and pasturelands) at the expense of natural ecosystems has led to an $11 \%$ decline in global mean biogenic volatile organic compound emissions. Concomitant growth in agricultural activity has more than doubled ammonia emissions and increased emissions of nitrogen oxides from soils by more than $50 \%$. Conversion to croplands has also led to a widespread increase in ozone dry deposition velocity. Together these changes in biosphere-atmosphere exchange have led to a $14 \%$ global mean increase in biogenic secondary organic aerosol (BSOA) surface concentrations, a doubling of surface aerosol nitrate concentrations, and local changes in surface ozone of up to $8.5 \mathrm{ppb}$. We assess a global mean LUC-DRF of $+0.017,-0.071$, and $-0.01 \mathrm{~W} \mathrm{~m}^{-2}$ for BSOA, nitrate, and tropospheric ozone, respectively. We conclude that the DRF and the perturbations in surface air quality associated with LUC (and the associated changes in agricultural emissions) are substantial and should be considered alongside changes in anthropogenic emissions and climate feedbacks in chemistry-climate studies.
\end{abstract}

\section{Introduction}

Humans have dramatically altered the land surface of the Earth, affecting over half of the land surface and permanently clearing over one-quarter of the planet's forests (Hurtt et al., 2006; Vitousek et al., 1997). Land use changes (LUCs) have accelerated with population growth, with $64 \%$ of cropland growth occurring since 1850 (Hurtt et al., 2011). These substantial shifts in land use have perturbed the exchange of carbon, water, and energy between the biosphere and atmosphere, impacting weather, and climate (Pielke et al., 2002; Pitman et al., 2009). LUC also alters the biosphereatmosphere exchange of gases and particles that impact air quality and contribute to short-lived radiative forcing; however, few studies have quantified these effects (Heald and Spracklen, 2015).

Particulate matter (PM) and tropospheric ozone are deleterious to human health and dominate uncertainty in current estimates of global climate forcing (IPCC, 2013). Air pollution is the leading environmental cause of premature mortality worldwide (OECD, 2012); exposure to ambient PM and surface ozone was responsible for over 3.7 million premature deaths in 2010 (Lim et al., 2013). The most recent IPCC estimates that tropospheric ozone and aerosols contribute +0.40 and $-0.35 \mathrm{~W} \mathrm{~m}^{-2}$ respectively to global direct radiative forcing (DRF) (IPCC, 2013). PM and ozone are short-lived climate pollutants, with lifetimes of about a week and about a month, respectively (Balkanski et al., 1993; Young et al., 2013). As a result, reductions in the concentrations of the warming components (ozone, black carbon) may be an effective strategy for mitigating near-term climate change (Shindell et al., 2012). At the same time, the short lifetimes of 
these species, coupled with the multitude of physical and chemical sources, limit confidence in estimated global climate forcing from these species (Myhre et al., 2013; Stevenson et al., 2013). In addition, the impact of anthropogenic land use change are not included in these estimates of PM and tropospheric ozone radiative forcing.

The terrestrial biosphere is a source of organics and nitrogen oxides $\left(\mathrm{NO}_{x}\right)$ that can contribute to $\mathrm{PM}$ and ozone formation. Biogenic volatile organic compounds (BVOC) emitted from vegetation, such as isoprene and monoterpenes, react quickly in the atmosphere to form low-volatility vapours that can condense to the particle phase and produce secondary organic aerosol (SOA) (Hallquist et al., 2009). Given sufficient $\mathrm{NO}_{x}$, this oxidation of BVOCs can also produce ozone. However, in clean, $\mathrm{NO}_{x}$-poor conditions, these BVOCs can react with and therefore consume ozone (Wang and Shallcross, 2000). The emission of BVOC depends strongly on the type and density of vegetation (Guenther et al., 2012). Similarly, microbial sources of nitrogen oxides from soils vary with land use, and with canopy density (Hudman et al., 2012). Managed ecosystems, such as croplands and pasturelands, are the dominant source of ammonia emissions to the atmosphere through emissions from fertilizer and domesticated animals (Erisman et al., 2008). In combination with nitric acid formed from the oxidation of $\mathrm{NO}_{x}$, ammonia can produce ammonium nitrate, an increasingly important source of inorganic PM in regions where sulfur emissions controls substantially reduce sulfate (Paulot et al., 2016; Pinder et al., 2007). The terrestrial biosphere is also a sink of gases and particles. In particular, the dry deposition of ozone at the surface accounts for $\sim 20 \%$ of the ozone loss in the troposphere (Stevenson et al., 2006). This removal is most efficient over high density vegetation and croplands via stomatal uptake. Perturbation to vegetation and transitions between land types alter these fluxes, with implications for $\mathrm{PM}$ and ozone.

Tree mortality, for example associated with insect infestation or disease, can modulate biosphere-atmosphere exchange, generating transitory perturbations in air quality (Berg et al., 2013; Geddes et al., 2016). However, conversion of land cover, for example via clearing, can lead to longterm changes in surface properties and therefore atmospheric composition. A number of studies have explored how both natural and anthropogenic future land use change may impact atmospheric chemistry (Ganzeveld et al., 2010; Heald et al., 2008; Wu et al., 2012). Few studies have explored the impact of historical land use change on PM and tropospheric ozone. As a result, anthropogenic land use change is absent from most estimates of radiative forcing from aerosols and tropospheric ozone. Ward et al. (2014) investigate the impact of land use and land cover change (LULCC) on greenhouse gases (including tropospheric ozone) and aerosols. They estimate that historical changes in LULCC result in a radiative forcing of $+0.12 \mathrm{~W} \mathrm{~m}^{-2}$ for ozone and $-0.04 \mathrm{~W} \mathrm{~m}^{-2}$ for aerosols $\left(-0.02 \mathrm{~W} \mathrm{~m}^{-2}\right.$ direct, $-0.02 \mathrm{~W} \mathrm{~m}^{-2}$ indirect) relative to 1850 . In this study the increase in ozone associated with LULCC is largely associated with the increase in methane and fires with partial compensation due to a $6 \%$ increase in ozone dry deposition. Their estimate of aerosol forcing is not disaggregated by species, but includes dust, biogenic SOA, and smoke. Unger (2014) suggests that land use change is responsible for $-0.13 \mathrm{~W} \mathrm{~m}^{-2}$ of radiative forcing from tropospheric ozone and $+0.09 \mathrm{~W} \mathrm{~m}^{-2}$ from biogenic SOA (direct only), primarily due to decreases in BVOC emissions since 1850 . These two assessments of radiative forcing of ozone and PM associated with land use do not agree on the sign of the forcing. However, it is critical to note that these studies differ fundamentally in design and in the processes and species considered, highlighting the complexity of this forcing and the need to quantify and compare specific impacts. A review of the potential impacts of land use change on air quality and climate suggests that historical LULCC has led to an aerosol direct radiative cooling of $\sim-0.10 \mathrm{~W} \mathrm{~m}^{-2}$, roughly $30 \%$ of current estimates of aerosol DRF (Heald and Spracklen, 2015). However, this review also points out the large uncertainty associated with these changes and the need for additional modelling studies on this topic. With this study, we aim to complement previous investigations and explore the impacts of historical global anthropogenic land use change on biosphereatmosphere exchange processes and the resulting perturbations to secondary PM and ozone.

\section{Model description}

To characterize the impact of historical land use change on air quality, we use v9-02 of the global chemical transport model GEOS-Chem (http://www.geos-chem.org). GEOSChem is driven by assimilated meteorology from the Global Modeling and Assimilation Office (GMAO). Here we use GEOS-5 meteorology for the year 2010. The native resolution $\left(0.5^{\circ} \times 0.67^{\circ}\right.$ horizontal resolution with 72 vertical levels) is degraded to $2^{\circ} \times 2.5^{\circ}$ and 47 vertical levels for computational efficiency.

The GEOS-Chem oxidant-aerosol simulation includes $\mathrm{H}_{2} \mathrm{SO}_{4}-\mathrm{HNO}_{3}-\mathrm{NH}_{3}$ aerosol thermodynamics described by ISORROPIA II (Fountoukis and Nenes, 2007; Pye et al., 2009) coupled to a detailed $\mathrm{HO}_{x}-\mathrm{NO}_{x}-\mathrm{VOC}-\mathrm{O}_{3}$ chemical mechanism. The model scheme also includes primary carbonaceous aerosols (Park et al., 2003), sea salt aerosol (Alexander et al., 2005; Jaeglé et al., 2011), and soil dust (Fairlie et al., 2007; Ridley et al., 2013). SOA is produced from the oxidation of biogenic hydrocarbons, aromatics, and IVOCs (intermediate volatility organic compounds) and represented with a volatility basis set approach (Pye et al., 2010; Pye and Seinfeld, 2010).

In this study, global anthropogenic emissions for 1850 and 2000 follow the Representative Concentration Pathway (RCP) historical emissions dataset (van Vuuren et al., 2011) 
as implemented by Holmes et al. (2013). These include fossil fuel, biofuel, and agricultural emissions. Fire emissions are specified using GFED3 for the year 2010 (van der Werf et al., 2010), consistent with the meteorology, and are fixed for all simulations. Methane concentrations are similarly fixed at year 2010 levels.

We use the GEOS-Chem land use module recently developed by Geddes et al. (2016) to specify consistent surface properties and to simulate surface-atmosphere exchange processes. These include the emissions of BVOC, the emission of $\mathrm{NO}_{x}$ from soils, and dry deposition of gases and particles. The land module uses 16 plant functional types (PFTs), consistent with those described by the Community Land Model (CLM) (Lawrence et al., 2011). The total leaf area index (LAI) is calculated interactively based on the PFT distribution and PFT-specific seasonal LAI taken from the CLM, derived from MODIS observations. BVOC emission factors for these PFTs are scaled online by activity factors describing emission response to light, temperature, leaf age, and $\mathrm{CO}_{2}$ following MEGAN v2.1 (Guenther et al., 2012). The PFTs are mapped to the biomes used for the soil $\mathrm{NO}_{x}$ emissions scheme described by Hudman et al. (2012). This parameterization includes biome-specific emissions, as well as reemission of wet and dry deposited nitrogen and fertilizer and manure nitrogen, all modulated online by temperature, soil moisture, and rain. Finally, dry deposition is based on the resistance-in-series scheme of Wesely (1989), with aerosolspecific deposition described by Zhang et al. (2001). The surface resistance for gases includes resistances to the ground, lower canopy, and vegetation, all of which are driven by fixed parameters for 11 land use types specified in the original Wesely (1989) parameterization. The PFTs are mapped to these 11 land use types. In addition, the aerodynamic resistance and quasi-laminar resistance calculations were altered to use biome-specific roughness heights (which will reflect specified land use), rather than values from the assimilated meteorological product.

To estimate the shortwave and longwave flux perturbations associated with tropospheric ozone and aerosols we apply the local (grid box) monthly mean radiative flux-to-burden relationship for each species archived from previous simulations (Heald et al., 2014) to changes in simulated burden. The simulation of Heald et al. (2014) uses a similar version of GEOS-Chem (v9.01.03) with identical meteorology and spatial resolution to the simulations explored in this study, ensuring that this offline application of radiative efficiency is a good approximation. We note that these radiative efficiencies are estimated using present-day land reflectances. The physical and optical properties assumed for aerosol species and the RRTMG radiative transfer model are described in Heald et al. (2014).

In this study we perform a series of simulations to explore the impact of land use change (and the associated changes in agricultural emissions) on ozone and aerosols (Table 1). All simulations are performed with year 2010 mete- orology, fire emissions, and methane concentrations. Land use change modulates surface albedo, energy, and water exchange (Pielke et al., 2002, 2011; Pitman et al., 2009), which may feedback on atmospheric composition (Ganzeveld et al., 2010; Ganzeveld and Lelieveld, 2004). Unger (2014) suggests that these feedbacks are small compared to the perturbation in BVOC emissions from historical land use change. By design, by fixing meteorology at year 2010, we do not quantify these impacts in this study. Rather, our simulations focus on the direct impact of changes in biosphereatmosphere exchange. By keeping methane concentrations constant we neglect changes in oxidative capacity driven by changes in local methane sources associated with agriculture (e.g. expansion of rice paddies, growth in livestock). Methane concentrations also do not respond to the changes in oxidative capacity associated with land-use-driven changes in short-lived precursor emissions (assessed in Sect. 5). Given the challenges associated with identifying dust regions produced from human-driven desertification (Ginoux et al., 2012), we keep this source constant and do not characterize the land use change impacts on dust. While land use change can produce large fire events, for example, deforestation fires associated with land clearing, these fires are typically transitory and vary considerably year to year (Hansen et al., 2013; van der Werf et al., 2010). Regular fire emissions associated with land use change, such as agricultural waste burning, make up less than $5 \%$ of global annual smoke emissions (van der Werf et al., 2010). Ward et al. (2014) explore the impacts of historical LULCC impacts on dust and smoke. In this study we focus on the impact of land use change on secondary aerosol and ozone formation. We also perform a set of simulations to separately estimate the impact of increasing agricultural emissions associated with land use change. In these simulations we assume that all changes in agricultural emissions of ammonia from 1850 to 2000 in the RCP emissions inventory are associated with land use change (i.e. conversion to either croplands or pastures). In addition, for 1850 agricultural emissions, we scale down the fertilizer source of soil $\mathrm{NO}_{x}$ emissions to $15.7 \%$ of year 2000 values (equivalent to the global 1850: 2000 ratio for agricultural sources of ammonia in the RCP emissions). We perform simulations to isolate the impact of anthropogenic land use change alone, agricultural emissions changes alone, and both together as described by Table 2 . We perform each set of simulations under both preindustrial (2000) and present-day (2000) anthropogenic (nonagricultural) emissions to bracket the potential range of these impacts depending on the background atmospheric conditions. We focus our results on the net impacts of land use change along with the associated changes in agricultural emissions (which we collectively refer to as LUC), unless otherwise specified. 
Table 1. List of GEOS-Chem simulations with relevant input parameters.

\begin{tabular}{lllll}
\hline & Simulation name & Land use & Anthropogenic (nonagricultural) emissions & Agricultural emissions \\
\hline 1 & 2000L2000E & 2000 & 2000 & 2000 \\
2 & 1850L2000E & 1850 & 2000 & 2000 \\
3 & 2000L1850E & 2000 & 1850 & 1850 \\
4 & 1850L1850E & 1850 & 1850 & 1850 \\
5 & 2000L2000E1850NH3 & 2000 & 2000 & 1850 \\
6 & 2000L1850E2000NH3 & 2000 & 1850 & 2000 \\
7 & 1850L2000E1850NH3 & 1850 & 2000 & 1850 \\
\hline
\end{tabular}

Table 2. Road map for how simulations are combined to estimate the impact of land use change and the associated change in agricultural emissions on air quality.

\begin{tabular}{lrr}
\hline & $\begin{array}{r}2000 \text { anthropogenic } \\
\text { emissions }\end{array}$ & $\begin{array}{r}1850 \text { anthropogenic } \\
\text { emissions }\end{array}$ \\
\hline Land use change alone & $1-2$ & $3-4$ \\
Agricultural emissions alone & $1-5$ & $6-3$ \\
Land use change + Agricultural emissions & $1-7$ & $6-4$ \\
\hline
\end{tabular}

\section{Land use change from 1850 to 2000}

Figure 1 shows the present-day (2000) distribution of vegetation used here grouped from 15 vegetated PFTs to 6 main vegetation categories for simplicity. The PFT distribution for the present day is the satellite phenology dataset used by CLM4, which is based on MODIS data and cropping datasets (Lawrence et al., 2011).

Figure 2 shows the change in vegetation distribution from preindustrial (1850) to the present day (2000) used here. The historical (1850) PFT distribution is specified as the Lawrence et al. (2012) CLM-specific adaptation of the Hurtt et al. (2011) harmonized land use dataset. The transition from historical to present day highlights the global growth of croplands, from 5.3 million to 14.7 million $\mathrm{km}^{2}$ at the expense of forests and grasslands. The net increase of 9.4 million $\mathrm{km}^{2}$ of croplands matches values provided by Hurtt et al. (2011), indicating that the mapping of this dataset to the CLM PFTs preserved the change in cropland coverage. The CLM PFTs do not include a separate pasturelands category; therefore changes in pasturelands (increase by 25.5 million $\mathrm{km}^{2}$ from 1850 to 2000) in the Hurtt et al. (2011) dataset are mapped to grasslands in the CLM dataset. Figure 2 shows some regional increases in grassland coverage consistent with pasture expansion. Finally, we note that much of the agricultural expansion in western Europe and eastern North America predates 1850 , and thus a trend towards a return to forestlands is evident in these regions in Fig. 2.

Figure 3 shows the change in LAI associated with the historical to present-day change in land use. Expansion of croplands leads to reductions in LAI, typically less than $20 \%$ locally. Globally, there is a $3 \%$ reduction in LAI due to land use alone. We note that the feedback of increasing $\mathrm{CO}_{2}$ fertilization on terrestrial productivity is not included here.

\section{Impact of historical anthropogenic land use change on emissions and deposition}

Table 3 summarizes the changes in emissions driven by land use change (and associated agricultural activities) simulated in GEOS-Chem for the historical transition from 1850 to 2000. Global annual mean BVOC emissions of isoprene, monoterpenes, and sesquiterpenes decline by $10-12 \%$ due to the expansion of croplands (Fig. 2), a vegetation class with very low basal emission rates for these BVOCs (Guenther et al., 2012). For example isoprene and $\alpha$-pinene emission factors for croplands are at least 2 orders of magnitude less than for needleleaf or broadleaf trees. The distribution of these reductions is shown in Fig. 4. Fractional declines are consistent year-round, with larger absolute decreases in summer at northern midlatitudes following the seasonality of vegetation. These changes are more modest than the $35 \%$ decrease in global BVOC emissions due to land use change estimated by Unger (2014) over the same time period. Unger (2014) follows the same historical land use trajectory used here (Hurtt et al., 2011) but the GISS model mapping of this dataset includes pasturelands as part of the cultivation biome, which also consists of croplands and does not emit BVOCs (N. Unger, personal communication, 2016). In contrast, the CLM approach maps pasturelands to grasslands, which are modest, but non-negligible, emitters of BVOCs. Therefore, the substantial difference between our estimate and that of Unger (2014) is associated with the uncertainty in characterizing BVOC basal emission rates from pasturelands, which expand significantly from 1850 to 2000 . Ward et al. (2014) estimate only a $1 \%$ increase in all biogenic emissions due to historical LULCC, but they do not disaggregate BVOCs and we cannot compare simulated changes in terpenes directly. 

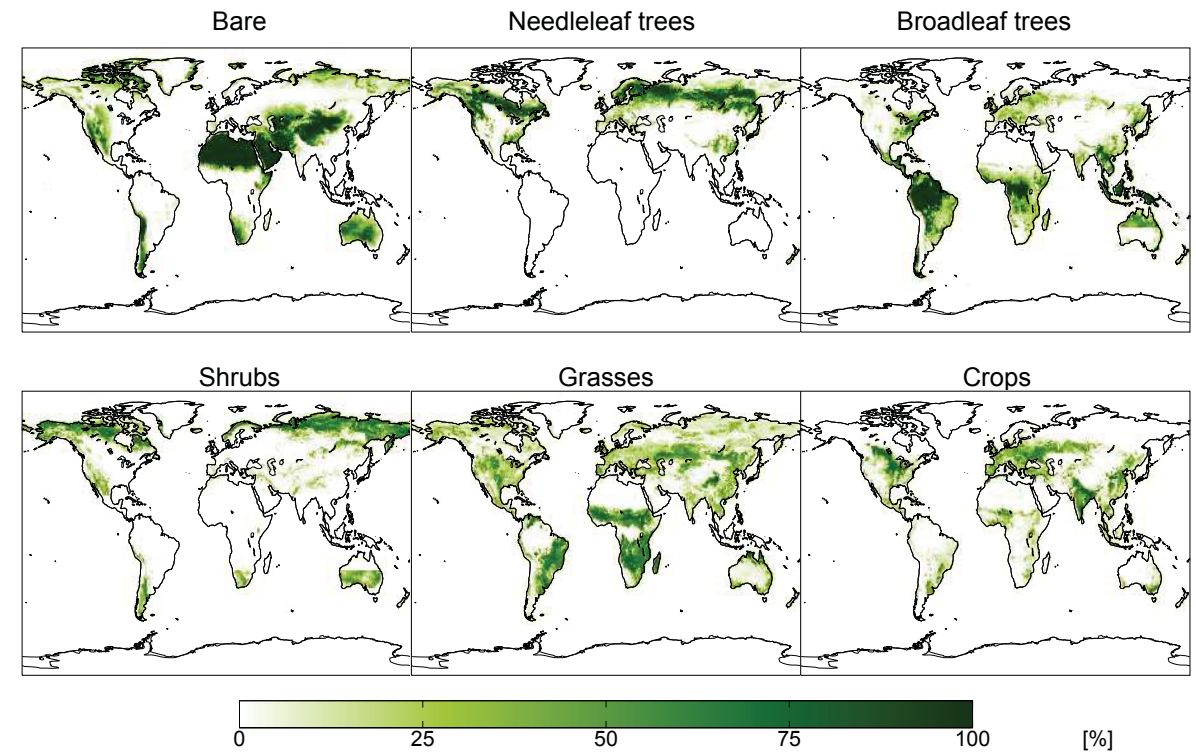

Figure 1. Present-day (year 2000) percentage of land area occupied by six classes of vegetation.
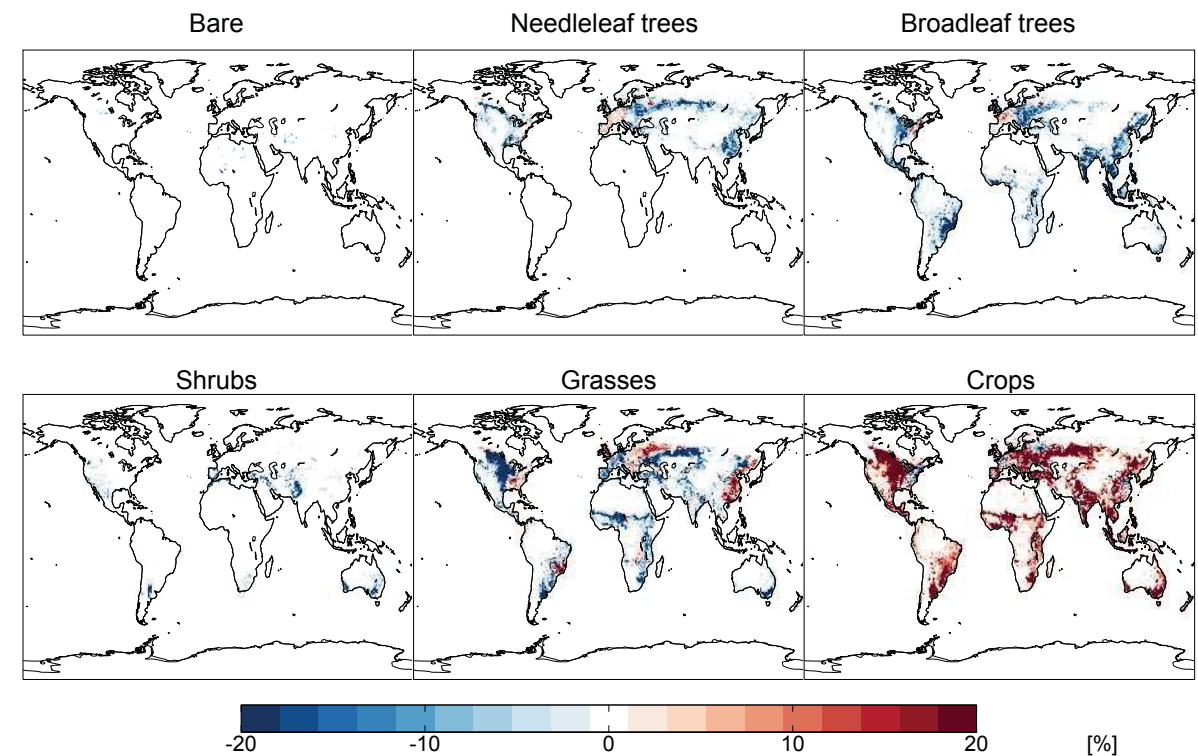

Figure 2. Change from preindustrial (1850) to present day (2000) in the percentage of land area occupied by six classes of vegetation.

Figure 5 shows the estimated increases in nitrogen emissions associated with LUC. Global annual mean nitrogen oxide emissions from soils increase by $3.7 \mathrm{TgN} \mathrm{yr}^{-1}$ (more than $50 \%$ ) from 1850 to 2000 . The majority of this increase $\left(2.9 \mathrm{TgN} \mathrm{yr}^{-1}\right)$ is associated with enhanced fertilizer usage in 2000 compared to 1850 , but emissions increase by $0.8 \mathrm{TgN} \mathrm{yr}^{-1}$ due to shifts in biomes (and the associated emission factors) as well as increased escape of $\mathrm{NO}_{x}$ from the canopy due to lower LAI in 2000 (Table 3). Relative changes in soil $\mathrm{NO}_{x}$ emissions are consistent year-round. Heald and Spracklen (2015) estimated a 50\% increase in soil $\mathrm{NO}_{x}$ emissions associated with LUC, in good agreement with our estimate here, but to our knowledge no study has simulated the change in soil $\mathrm{NO}_{x}$ emissions due to historical LUC. These results highlight the need to better constrain changes in soil $\mathrm{NO}_{x}$ emissions due to fertilizer application over the last 150 years (Felix and Elliott, 2013). Figure 5 also shows that total ammonia emissions more than double from 1850 to 2000 due to agricultural sources, following the RCP emissions (van Vuuren et al., 2011). This reflects substantial increases in fertilizer usage on croplands and domesticated animals on pasturelands. 
Table 3. Annual average emissions impacted by historical land use change alone; shown separately are changes in emissions due to both land use change and associated agricultural emissions.

\begin{tabular}{|c|c|c|c|c|c|c|}
\hline & \multicolumn{3}{|c|}{ Land use change alone } & \multicolumn{3}{|c|}{$\begin{array}{l}\text { Land use change }+ \text { associated } \\
\text { agricultural emissions }\end{array}$} \\
\hline & 1850 & 2000 & $\%$ change & 1850 & 2000 & $\%$ change \\
\hline Isoprene $\left(\mathrm{Tg} \mathrm{yr}^{-1}\right)$ & 518 & 459 & $-11.4 \%$ & 518 & 459 & $-11.4 \%$ \\
\hline Monoterpenes $\left(\mathrm{Tg} \mathrm{yr}^{-1}\right)$ & 188 & 165 & $-12.0 \%$ & 188 & 165 & $-12.0 \%$ \\
\hline Sesquiterpenes $\left(\mathrm{Tg} \mathrm{yr}^{-1}\right)$ & 23.8 & 21.3 & $-10.6 \%$ & 23.8 & 21.3 & $-10.6 \%$ \\
\hline Ammonia $\left(\mathrm{Tg} \mathrm{yr}^{-1}\right)$ & 59.3 & 59.3 & $0.0 \%$ & 28.4 & 59.3 & $+109 \%$ \\
\hline Soil $\mathrm{NO}_{x}\left(\mathrm{TgN} \mathrm{yr}^{-1}\right)^{*}$ & 9.2 & 10.0 & $+8.4 \%$ & 6.3 & 10.0 & $+58.5 \%$ \\
\hline
\end{tabular}

Table 4. Annual average tropospheric burden (Tg) of key species. Also shown is the changes driven by historical land use change (including associated agricultural emissions). Values estimated using year 2000 anthropogenic emissions and 1850 anthropogenic emissions are shown.

\begin{tabular}{lrrr|rrr}
\hline & \multicolumn{2}{c|}{ Year 2000 anthropogenic emissions } & \multicolumn{2}{c}{ Year 1850 anthropogenic emissions } \\
\hline & 1850 & 2000 & $2000-1850(\%)$ & 1850 & 2000 & $2000-1850(\%)$ \\
\hline Biogenic SOA & 0.59 & 0.52 & $-0.076(-13 \%)$ & 0.58 & 0.50 & $-0.076(-13 \%)$ \\
O $_{3}$ & 266 & 262 & $-4.2(-1.6 \%)$ & 231 & 228 & $-3.1(-1.4 \%)$ \\
Ammonia & 0.05 & 0.14 & $+0.09(+190 \%)$ & 0.09 & 0.28 & $+0.19(+219 \%)$ \\
Nitrate & 0.07 & 0.31 & $+0.25(+374 \%)$ & 0.07 & 0.27 & $+0.20(+305 \%)$ \\
\hline
\end{tabular}

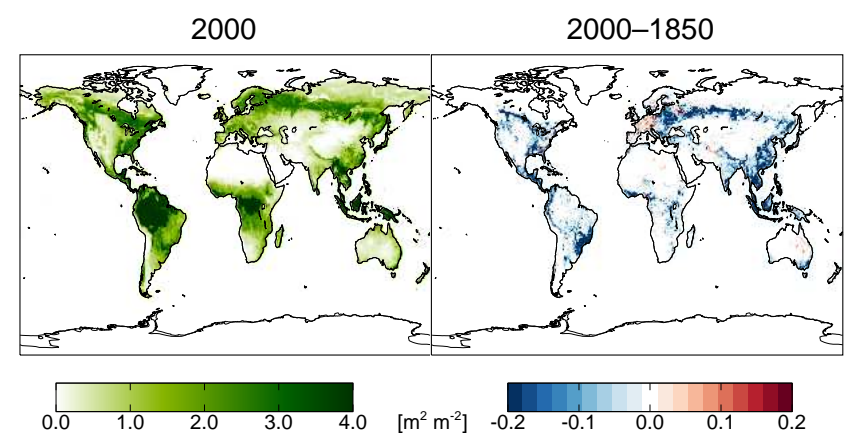

Figure 3. Annual average leaf area index (LAI) in present day (left) and the change in LAI from preindustrial (1850) to present day (2000) (right).

Historical LUC also modifies the surface properties that control the uptake of gases at the surface. This loss is most significant for tropospheric ozone, a relatively insoluble gas, which is biologically reactive and is therefore readily taken up by vegetation (Stevenson et al., 2006; Wesely and Hicks, 2000). The response of ozone dry deposition velocity to changes in land use is dominated by changes to surface resistance. Therefore changes to the aerodynamic resistances due to differences in roughness height (which increases from grassland to agriculture to forests; see Table A1 of Geddes et al., 2016) do not substantially impact the simulated ozone
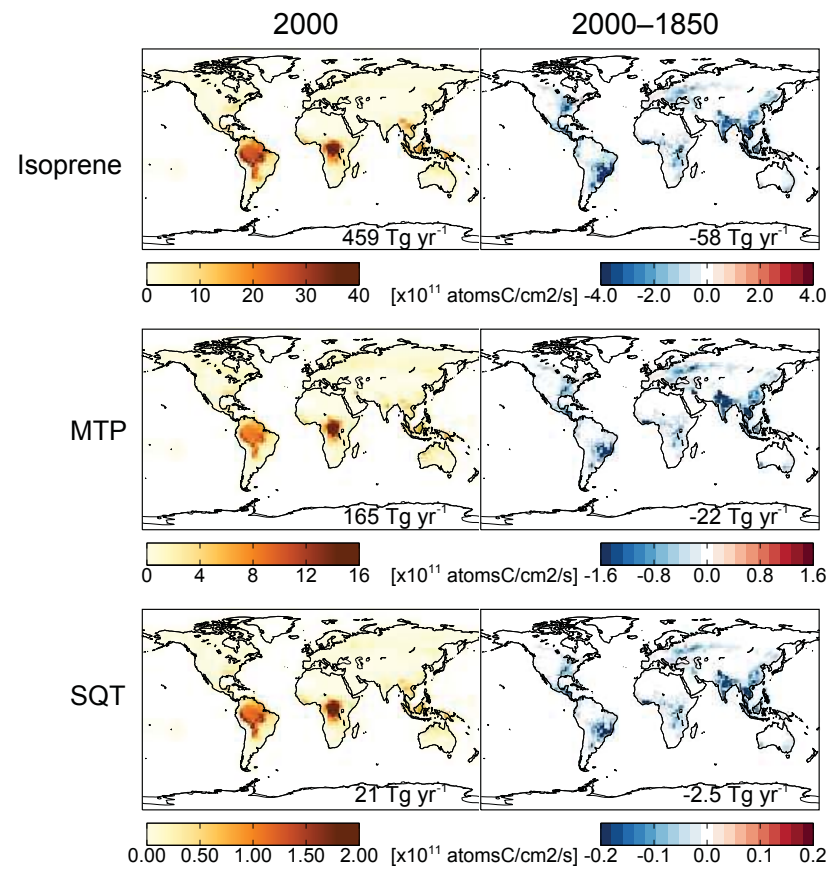

Figure 4. Annual mean simulated emissions of BVOCs from vegetation. Total emissions for present day (2000) shown on the left; the change due to historical land use change is shown on the right. Global annual emission values are shown inset. 

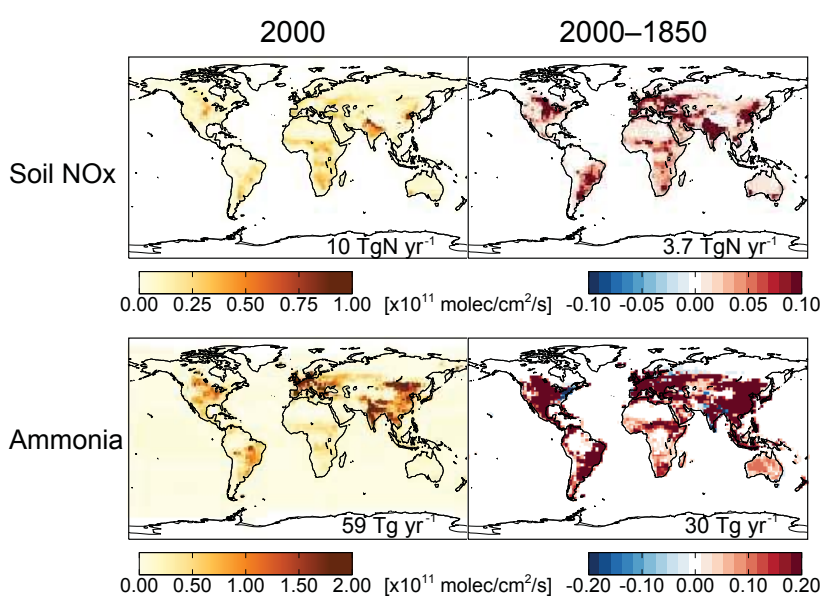

Figure 5. Annual mean emissions of nitrogen oxides from soils (top row) and ammonia (bottom). Total emissions for present day (2000) shown on the left; the change due to historical land use change (and the associated agricultural emissions) is shown on the right. Global annual emission values are shown inset.

dry deposition. Figure 6 shows that historical LUC has modestly increased $\mathrm{O}_{3}$ deposition velocities over most regions where croplands have expanded. This increase is driven by lower stomatal and surface resistance values associated with croplands (compared to forests and grasslands) in the Wesely (1989) scheme. This effect outweighs the decreases in deposition velocity associated with decreases in LAI over croplands (Fig. 3). However, this is not the case in Southeast Asia, where replacement of dense tropical forests with croplands substantially decreases LAI (Fig. 3), driving down deposition velocities. Local decreases in deposition velocity over western Europe and the eastern United States are the result of reforestation of croplands since 1850. In southeastern Brazil, expansion of pasturelands (shown as grasslands in Fig. 2) at the expense of broadleaf trees leads to a decrease in deposition velocity. Local differences do not exceed $20 \%$ and are typically less than $10 \%$. Historical LUC produces less than $1 \%$ difference in global mean ozone deposition velocity. Changes in deposition velocity shown in Figure 6 are relatively aseasonal, with somewhat larger changes in summer at northern midlatitudes associated with peak vegetation density. Verbeke et al. (2015) explore the impact of future LUC in 2050 on the deposition of ozone. Qualitatively their simulated response to cropland expansion and reforestation are consistent with our results, with local changes to deposition velocities that are within $10 \%$.

\section{Impact of historical anthropogenic land use change on atmospheric composition}

The response of atmospheric composition to changes in biosphere-atmosphere fluxes depends on the assumed anthropogenic emissions; we first present results using present-

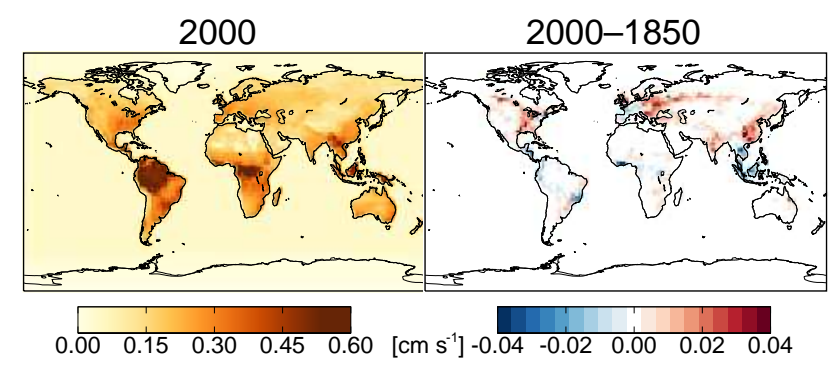

Figure 6. Annual mean simulated dry deposition velocity of ozone for present day (2000) shown on the left; the change due to historical land use change is shown on the right.

day (2000) anthropogenic emissions and then comment on differences when instead employing preindustrial (1850) anthropogenic emissions (Tables 1 and 2).

Figures 7 and 8 show the impact of historical LUC on boreal summer (June-August) and winter (DecemberFebruary) mean surface concentrations of key species. The decline in BVOC emissions driven by the expansion of croplands leads directly to widespread decreases in biogenic SOA (BSOA). Surface concentrations decrease by $14 \%$ on average; local BSOA concentrations in summertime decrease by up to $84 \%$ and increase by up to $54 \%$ over western Europe and eastern USA, where BVOC emissions increase due to reforestation (see Figs. 2, 3, and 4). The global annual mean tropospheric burden of BSOA decreases by $13 \%$ due to historical LUC (Table 4).

The more than doubling of ammonia emissions from preindustrial conditions to present day associated with agricultural activities (Table 3) dramatically enhances ammonium nitrate formation. This increase is particularly evident in northern midlatitudes winter (Fig. 8), where cool temperatures favour nitrate formation and mean surface nitrate concentrations more than double. The global annual mean tropospheric burden of aerosol nitrate increases almost 4-fold due to historical LUC (Table 4). This increase is almost entirely the result of ammonia emissions increases; land use change alone (simulations 1 vs. 2; see Tables 1 and 2) increases the tropospheric burden of nitrate by only $1.1 \%$, stemming from the enhanced soil $\mathrm{NO}_{x}$ emissions. These results are consistent with Bauer et al. (2016), who estimate that agriculture is responsible for $78 \%$ of ammonia emissions and that this is the prevailing source of ammonium nitrate formation in the Northern Hemisphere.

In summer, surface $\mathrm{NO}_{x}$ concentrations are locally enhanced by LUC (Fig. 7), driven by elevated soil $\mathrm{NO}_{x}$ emissions. Despite this, we see that surface ozone concentrations decrease in the Northern Hemisphere. These decreases reflect elevated ozone deposition over croplands (Fig. 6) and decreases in BVOC emissions (Fig. 4). Summertime mean surface ozone decreases by up to $8.5 \mathrm{ppb}$, with at least a $1 \mathrm{ppb}$ decrease throughout the Northern Hemisphere. The changes in emissions and uptake over the Southern Hemisphere lead 


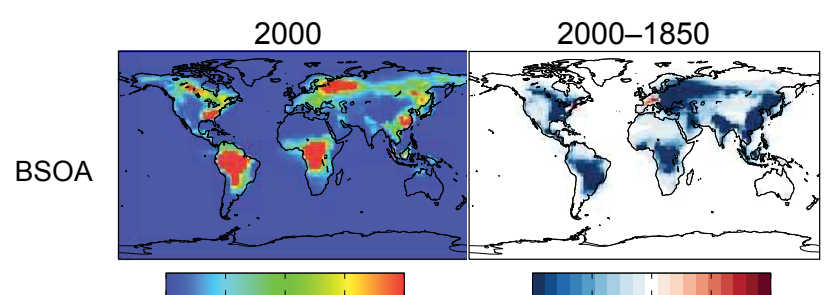

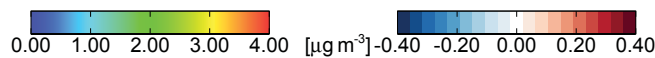

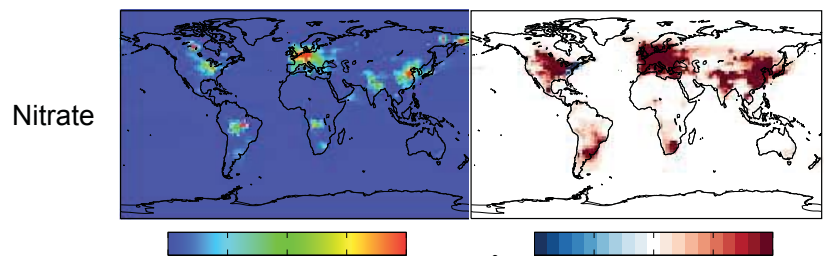

$\begin{array}{lllllllllll}0.00 & 1.25 & 2.50 & 3.75 & 5.00 & {\left[\mu \mathrm{g} \mathrm{m}^{-3}\right]} & -0.50 & -0.25 & 0.00 & 0.25 & 0.50\end{array}$
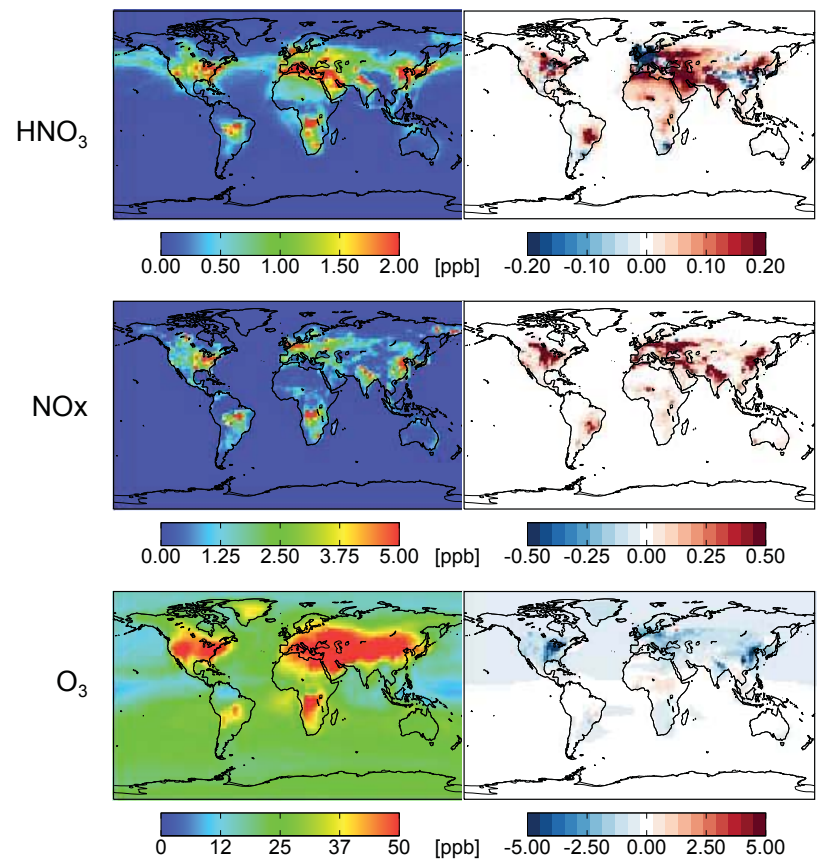

Figure 7. Boreal summertime (June-August) mean simulated surface concentrations of biogenic SOA (BSOA), aerosol nitrate, nitric acid $\left(\mathrm{HNO}_{3}\right)$, nitrogen oxides $\left(\mathrm{NO}_{x}\right)$, and ozone. Concentrations for present day (2000) shown on the left; the change due to historical land use change is shown on the right. All simulations performed with present-day (2000) anthropogenic emissions; shown here are the differences between simulations 1 and 7 (see Tables 1 and 2).

to negligible changes in surface ozone (generally less than $1 \mathrm{ppb})$.

In winter, the large additional pool of atmospheric ammonia associated with anthropogenic LUC pulls nitric acid into the particle phase. As a result, nitric acid surface concentrations decrease by over $50 \%$ throughout the Northern Hemisphere (Fig. 8). This reduces $\mathrm{NO}_{x}$ recycling from nitric acid, leading to an overall decrease in $\mathrm{NO}_{x}$ concentrations despite increases in soil $\mathrm{NO}_{x}$ emissions. Thus in winter, historical LUC has led to a drop in $\mathrm{NO}_{x}$ and $\mathrm{BVOC}$ concentrations in
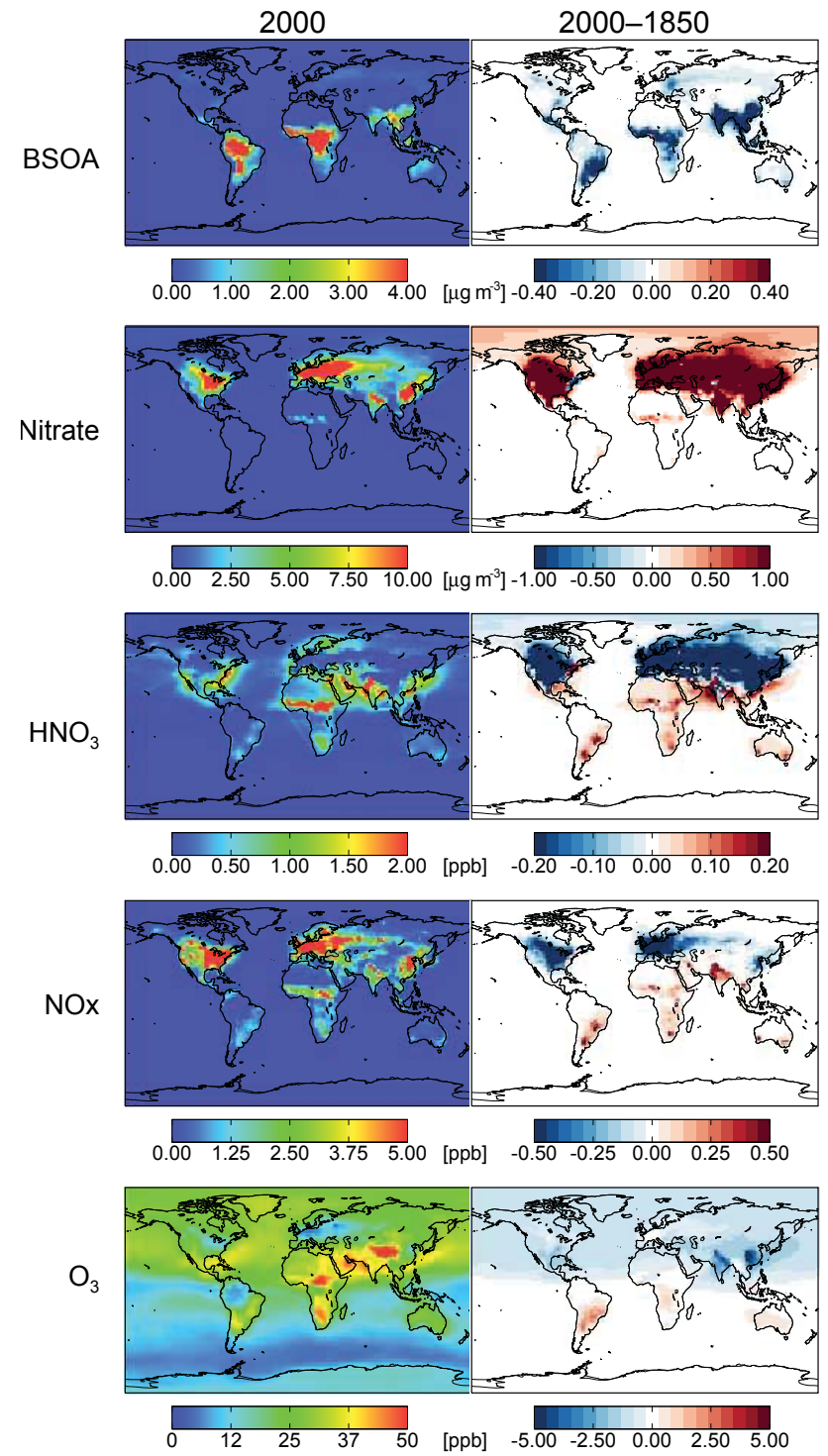

Figure 8. Boreal wintertime (December-February) mean simulated surface concentrations of biogenic SOA (BSOA), aerosol nitrate, nitric acid $\left(\mathrm{HNO}_{3}\right)$, nitrogen oxides $\left(\mathrm{NO}_{x}\right)$, and ozone. Concentrations for present day (2000) shown on the left; the change due to historical land use change is shown on the right. All simulations performed with present-day (2000) anthropogenic emissions; shown here are the differences between simulations 1 and 7 (see Tables 1 and 2).

the Northern Hemisphere, while ozone deposition velocities increase. Therefore, wintertime ozone decreases over northern midlatitudes are of similar magnitude as in summer (up to $6.6 \mathrm{ppb}$, generally 1-2 ppb) despite reduced photochemical production of ozone, and thus lower absolute concentrations, in wintertime. Ozone changes in the Southern Hemisphere in winter remain small, but local increases of up to $2.5 \mathrm{ppb}$ are simulated. In these $\mathrm{NO}_{x}$ limited regions, increases in soil $\mathrm{NO}_{x}$ emissions enhance ozone production and decreases in 

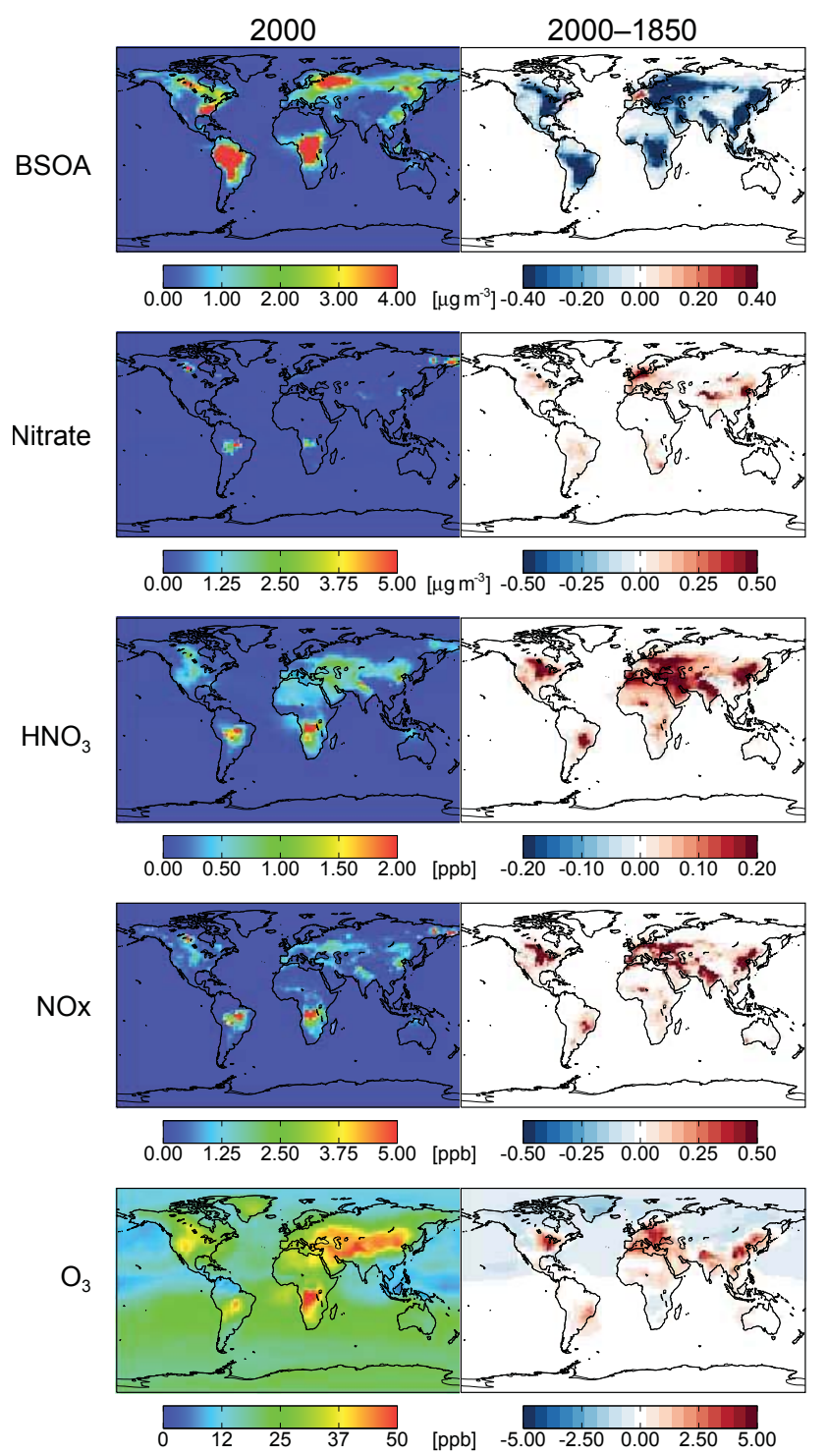

Figure 9. Boreal summertime (June-August) mean simulated surface concentrations of biogenic SOA (BSOA), aerosol nitrate, nitric acid $\left(\mathrm{HNO}_{3}\right)$, nitrogen oxides $\left(\mathrm{NO}_{x}\right)$, and ozone. Concentrations for present day (2000) shown on the left; the change due to historical land use change is shown on the right. All simulations performed with preindustrial (1850) anthropogenic emissions; shown here are the differences between simulations 6 and 4 (see Tables 1 and 2). Shown with same colour bars as Fig. 7 for comparison.

BVOC emissions reduce the sink of ozone via isoprene oxidation. In some regions, such as eastern Brazil, decreases in ozone deposition velocity due to expansion of pasturelands (Fig. 6) bolster this enhancement.

While these changes in surface ozone concentrations are small, they are comparable to the so-called "climate penalty" increases in ozone associated with a warming climate (Tai et al., 2013; Wu et al., 2008). This suggests that both historical analyses and future projections of ozone air qual-
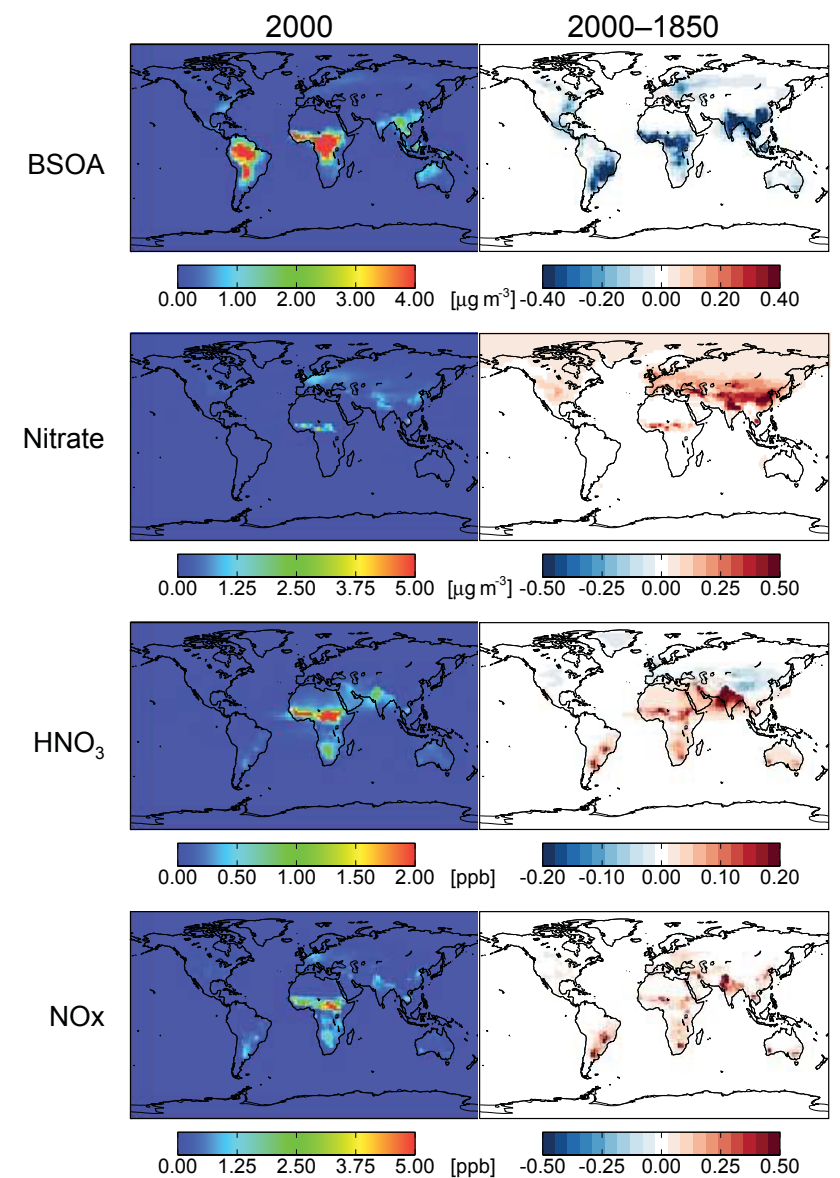

$\mathrm{O}_{3}$

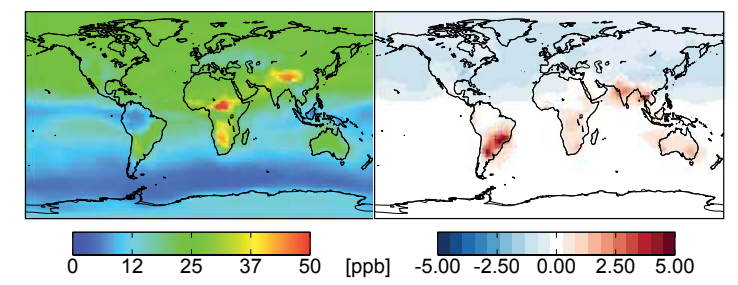

Figure 10. Boreal wintertime (December-February) mean simulated surface concentrations of biogenic SOA (BSOA), aerosol nitrate, nitric acid $\left(\mathrm{HNO}_{3}\right)$, nitrogen oxides $\left(\mathrm{NO}_{x}\right)$, and ozone. Concentrations for present day (2000) shown on the left; the change due to historical land use change is shown on the right. All simulations performed with preindustrial (1850) anthropogenic emissions; shown here are the differences between simulations 6 and 4 (see Tables 1 and 2). Shown with same colour bars as Fig. 8 for comparison.

ity should consider land use conversion alongside emissions when characterizing the impacts of anthropogenic activities. Table 4 shows that the net annual mean tropospheric burden of ozone decreases only by $1.6 \%$ due to historical LUC, suggesting that ozone impacts on radiative forcing are considerably more modest. Global mean tropospheric $\mathrm{OH}$ changes by less than $0.5 \%$ due to historical LUC. Therefore in our sim- 
ulations historical LUC has little impact on the tropospheric oxidative capacity or the tropospheric methane lifetime.

The above results characterize changes assuming that anthropogenic emissions are fixed at year 2000 levels. While it is necessary to fix anthropogenic emissions to isolate and quantify the effect of LUC, in reality, anthropogenic emissions and land use co-evolve. Thus, it is equally valid to assess the impact of LUC with simulations where anthropogenic emissions are fixed at 1850 fluxes (note that methane remains at year 2010 levels in these simulations). As shown in Table 2, we repeat all our simulations with these alternate anthropogenic emissions. Table 4 shows the global mean tropospheric burdens assessed under this scenario. Figures 9 and 10 can be compared to Figs. 7 and 8 and show seasonal mean changes in surface concentrations when anthropogenic (nonagricultural) emissions are fixed at 1850 levels. Biogenic SOA burdens and concentrations are relatively unaffected by differences in anthropogenic emissions; very minor differences are associated with changes in oxidant levels. While the surface concentrations of $\mathrm{NO}_{x}, \mathrm{HNO}_{3}$, and aerosol nitrate simulated under 1850 anthropogenic emissions are all considerably lower than estimated using year 2000 emissions, the qualitative patterns associated with LUC presented in Figs. 9 and 10 are consistent, though more modest, than those presented in Figs. 7 and 8. We see from Table 4 that, with 1850 anthropogenic emissions, ammonium nitrate formation is $\mathrm{NO}_{x}$ limited and a significant fraction of the ammonia emissions increase due to agricultural sources remains in the gas phase. Thus, the absolute increase in nitrate aerosol burden due to LUC is somewhat smaller (by $17 \%$ ) than estimated using year 2000 anthropogenic emissions. As seen in Figs. 9 and 10 surface concentrations are more sensitive to these effects with much smaller absolute concentration changes when using 1850 anthropogenic emissions (increases of less than $1 \mu \mathrm{g} \mathrm{m}^{-3}$ in Fig. 10 compared to widespread increases of more than $5 \mu \mathrm{g} \mathrm{m}^{-3}$ when using 2000 anthropogenic emissions in Fig. 8). This suggests that while ammonium nitrate formation is dramatically curtailed at the surface when anthropogenic $\mathrm{NO}_{x}$ emissions are low, formation of ammonium nitrate in the free troposphere is not substantially impacted by reductions in anthropogenic $\mathrm{NO}_{x}$. Thus, the increase in surface nitrate from preindustrial to present day is controlled more by the rise in anthropogenic $\mathrm{NO}_{x}$ emissions than the rise in agricultural ammonia emissions, while the increase in the burden of tropospheric nitrate is driven primarily by the increase in ammonia. Finally, while the change in global mean tropospheric burden of ozone is similar whether assuming 1850 or 2000 anthropogenic emissions, some spatial differences are apparent in surface concentrations. In particular, summertime surface $\mathrm{O}_{3}$ concentrations locally increase (by up to $5 \mathrm{ppb}$ ) over northern hemispheric midlatitudes regions (Fig. 9) where soil $\mathrm{NO}_{x}$ emissions increase due to LUC (Fig. 5). Ozone production is widely $\mathrm{NO}_{x}$ limited under 1850 anthropogenic emissions, and thus the ozone production efficiency of additional soil

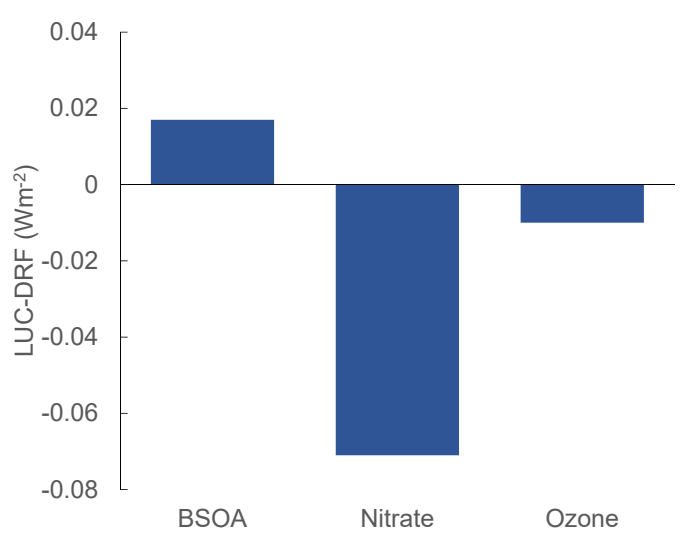

Figure 11. Global annual mean direct radiative forcing associated with anthropogenic land use change (LUC-DRF) from 1850 to 2000.

$\mathrm{NO}_{x}$ emissions is considerably higher, and outweighs the impact of elevated deposition velocities for ozone due to LUC.

\section{Direct radiative impacts of historical anthropogenic land use change}

The changes in annual mean tropospheric burden under 1850 and 2000 anthropogenic emissions shown in Table 4 bracket the potential impact of historical LUC on secondary PM and ozone. To estimate the change in direct radiative fluxes associated with historical LUC we apply monthly mean radiative efficiencies for BSOA, nitrate, and tropospheric ozone estimated from previous GEOS-Chem simulations (see Sect. 2) to our results using 2000 anthropogenic emissions. As this change is directly driven by anthropogenic LUC it represents the direct radiative forcing associated with land use change (LUC-DRF). Figure 11 summarizes these results.

The largest radiative impact from historical LUC in our simulations is a cooling of $-0.071 \mathrm{~W} \mathrm{~m}^{-2}$ associated with the rise in nitrate aerosol from preindustrial to the present day. This increase is driven almost entirely by increases in ammonia emissions. The LUC-DRF of nitrate constitutes $81 \%$ of the total direct radiative effect (DRE) of nitrate. Heald and Spracklen (2015) estimate a stronger LUCcooling associated with nitrate $\left(-0.094 \mathrm{~W} \mathrm{~m}^{-2}\right)$, but this back-of-the-envelope calculation is based on a stronger overall radiative effect of nitrate.

We estimate that decreases in BSOA due to historical LUC have produced a warming of $+0.017 \mathrm{~W} \mathrm{~m}^{-2}$. This LUC-DRF is $\sim 10 \%$ of the DRE of BSOA in our simulations. This value is smaller than the LULCC change in DRE $\left(+0.034 \mathrm{~W} \mathrm{~m}^{-2}\right)$ estimated by Heald and Spracklen (2015), but the later included $\mathrm{CO}_{2}$ fertilization and inhibition effects and is therefore not directly comparable. The LUC-DRF of tropospheric ozone associated with the very small changes in global burden discussed in Sect. 5 is a cooling of $-0.01 \mathrm{~W} \mathrm{~m}^{-2}$. Ward 
et al. (2014) estimate a LUC-DRF of opposite sign for ozone $\left(+0.12 \mathrm{~W} \mathrm{~m}^{-2}\right)$, but this value primarily reflects changes in methane and fire emissions, which we do not consider here; Ward et al. (2014) do not quantify the change in BVOC emissions. Our results are qualitatively consistent with the LUC-DRF of BSOA and tropospheric ozone estimated by Unger (2014) but are considerably more modest. This largely arises from the smaller change in BVOC emissions estimated in our study ( $\sim 11 \%$ ) compared to Unger (2014) (35\%) due to different classifications of pasturelands and their associated BVOC emissions (see Sects. 3 and 4).

\section{Conclusions}

This study explores the simulated impact of historical LUC on air quality and DRF, with an emphasis on secondary formation of PM and tropospheric ozone. Land use change from preindustrial (1850) to the present day (2000) is chiefly defined by cropland and pastureland expansion worldwide, as well as local reforestation in western Europe and the eastern United States. This has led to a global decline in BVOC emissions (by $\sim 11 \%$ ), but the associated agricultural sources have increased emissions of both ammonia (by a factor of 2) and soil nitrogen oxides (by $50 \%$ ). At the same time, surface uptake has been impacted by changes in vegetation type and density. Generally, we find that ozone deposition velocities have increased due to LUC, with some local exceptions associated with reforestation and expansion of pasturelands.

These LUC-driven changes in biosphere-atmosphere exchange processes work in concert to directly impact the secondary formation of BSOA, aerosol nitrate, and ozone. Surface air quality is significantly impacted by these changes, with a $14 \%$ average decrease in BSOA concentrations, a more than doubling of mean nitrate concentrations, and changes in surface $\mathrm{O}_{3}$ of up to $8.5 \mathrm{ppb}$. We find that changes to ozone surface concentrations in the Northern Hemisphere are sensitive to the assumed anthropogenic emissions. This reflects the changing balance of deposition and precursor emissions of BVOCs and $\mathrm{NO}_{x}$ in controlling ozone concentrations under varying $\mathrm{NO}_{x}$ levels. Associated with these changes we estimate a DRF associated with LUC for nitrate $\left(-0.071 \mathrm{~W} \mathrm{~m}^{-2}\right)$, BSOA $\left(+0.017 \mathrm{~W} \mathrm{~m}^{-2}\right)$, and tropospheric ozone $\left(-0.01 \mathrm{~W} \mathrm{~m}^{-2}\right)$. We note that these estimates are obtained with fixed 2010 meteorology, and therefore we have not assessed the interannual climate variability against which these values can be compared for significance. While this is certainly not the first study to estimate the DRF of nitrate, few models have routinely assess this (Myhre et al., 2013), and to our knowledge this is the first that assesses the nitrate DRF associated with LUC. This study suggests that BSOA concentrations were elevated in the more extensively forested preindustrial era. This higher preindustrial burden of natural aerosol may temper the indirect aerosol effect (Carslaw et al., 2013; Menon et al., 2002), which we do not assess here. We attribute differences between our more modest estimates of LUC-DRF for BSOA and $\mathrm{O}_{3}$ and those of Unger (2014) to differing treatments of pasturelands in the respective models, and thus the assumed BVOC basal emission rate for pasturelands. These substantial differences in LUC-DRF highlight how uncertainty in the representation of historical land use change in Earth system models leads to large uncertainties in global chemical composition.

This study examines only a subset of the emissions that may be impacted by LUC. In particular, we do not assess the changes in primary PM associated with LUC, including dust, smoke, and bioaerosol. It remains challenging to disaggregate the natural and anthropogenic influences on these emissions. In addition, we fix methane concentrations and therefore do not comprehensively assess how changes in global oxidative capacity driven by LUC may impact secondary aerosol and ozone formation. We also do not consider the meteorological feedbacks on atmospheric composition associated with land use change; more work is needed to quantify how these feedbacks compare to the direct perturbations associated with biosphere-atmosphere exchange. Thus, this study quantifies only part of the impacts of LUC. Furthermore, as our results rely heavily on the parameterization of biosphere-atmosphere exchange processes, more work is needed to validate these emissions and deposition schemes (e.g. Hardacre et al., 2015). In addition, given uncertainties in BSOA formation (Hallquist et al., 2009) and the general underestimate of organic aerosol in global models, including GEOS-Chem (Heald et al., 2011), the absolute magnitude of the impact of LUC on both air quality and DRF via BSOA may be underestimated here. Finally, uncertainties associated with the gas-phase oxidation chemistry of isoprene, monoterpenes, and sesquiterpenes may impact our simulated sensitivity of BSOA and $\mathrm{O}_{3}$ to LUC. The simulations analysed in this study were performed with one chemical transport model (GEOS-Chem); the degree to which model-specific treatments of chemical oxidation, aerosol formation, emissions, removal, and meteorology may impact the results cannot be assessed here. Thus, additional modelling investigations using alternate model schemes are required to better characterize the uncertainty surrounding the impact of land use change on air quality and climate forcing.

We find that historical land use change has brought about substantial changes in secondary PM and ozone formation, impacting air quality and direct radiative forcing. The magnitude of these changes are comparable to the feedbacks associated with climate change (Tai et al., 2012, 2013). Furthermore, in an era of declining emissions of air pollution precursors (Smith and Bond, 2014), anthropogenic land use change may become the dominant human impact on atmospheric composition. Therefore, more work is needed to improve our understanding and parameterization of biosphereatmosphere exchange processes and how these are altered by changing vegetation. 


\section{Data availability}

The GEOS-Chem model output data used in this study are archived at MIT and are available upon request from the authors (heald@mit.edu).

Acknowledgements. This work was supported by NSF (ATM0929282 and ATM-1564495). Jeffrey A. Geddes acknowledges support from an NSERC CREATE IACPES postdoctoral fellowship and travel grant.

Edited by: Q. Zhang

Reviewed by: N. Unger and one anonymous referee

\section{References}

Alexander, B., Park, R. J., Jacob, D. J., Li, Q. B., Yantosca, R. M., Savarino, J., Lee, C. C. W., and Thiemens, M. H.: Sulfate formation in sea-salt aerosols: Constraints from oxygen isotopes, J. Geophys. Res.-Atmos., 110, D10307, doi:10.1029/2004JD005659, 2005.

Balkanski, Y. J., Jacob, D. J., Gardner, G. M., Graustein, W. C., and Turekian, K. K.: Transport and Residence Times of Tropospheric Aerosols Inferred from a Global 3-dimensional Simulation of Pb210, J. Geophys. Res.-Atmos., 98, 20573-20586, 1993.

Bauer, S. E., Tsigaridis, K., and Miller, R.: Significant atmospheric aerosol pollution caused by world food cultivation, Geophys. Res. Lett., 43, 5394-5400, 2016.

Berg, A. R., Heald, C. L., Huff Hartz, K. E., Hallar, A. G., Meddens, A. J. H., Hicke, J. A., Lamarque, J.-F., and Tilmes, S.: The impact of bark beetle infestations on monoterpene emissions and secondary organic aerosol formation in western North America, Atmos. Chem. Phys., 13, 3149-3161, doi:10.5194/acp-13-31492013, 2013.

Carslaw, K. S., Lee, L. A., Reddington, C. L., Pringle, K. J., Rap, A., Forster, P. M., Mann, G. W., Spracklen, D. V., Woodhouse, M. T., Regayre, L. A., and Pierce, J. R.: Large contribution of natural aerosols to uncertainty in indirect forcing, Nature, 503, 67-71, 2013.

Erisman, J. W., Sutton, M. A., Galloway, J., Klimont, Z., and Winiwater, W.: How a century of ammonia synthesis changed the world, Nat. Geosci., 1, 636-639, 2008.

Fairlie, T. D., Jacob, D. J., and Park, R. J.: The impact of transpacific transport of mineral dust in the United States, Atmos. Environ., 41, 1251-1266, 2007.

Felix, J. D. and Elliott, E. M.: The agricultural history of humannitrogen interactions as recorded in ice core delta N-15-NO3, Geophys. Res. Lett., 40, 1642-1646, 2013.

Fountoukis, C. and Nenes, A.: ISORROPIA II: a computationally efficient thermodynamic equilibrium model for $\mathrm{K}^{+}$$\mathrm{Ca}^{2+}-\mathrm{Mg}^{2+}-\mathrm{NH}_{4}^{+}-\mathrm{Na}^{+}-\mathrm{SO}_{4}^{2-}-\mathrm{NO}_{3}^{-}-\mathrm{Cl}^{-}-\mathrm{H}_{2} \mathrm{O}$ aerosols, Atmos. Chem. Phys., 7, 4639-4659, doi:10.5194/acp-7-4639-2007, 2007.

Ganzeveld, L. and Lelieveld, J.: Impact of Amazonian deforestation on atmospheric chemistry, Geophys. Res. Lett., 31, L06105, doi:10.1029/2003g1019205, 2004.
Ganzeveld, L., Bouwman, L., Stehfest, E., van Vuuren, D. P., Eickhout, B., and Lelieveld, J.: Impact of future land use and land cover changes on atmospheric chemistryclimate interactions, J. Geophys. Res.-Atmos., 115, D23301, doi:10.1029/2010jd014041, 2010.

Geddes, J. A., Heald, C. L., Silva, S. J., and Martin, R. V.: Land cover change impacts on atmospheric chemistry: simulating projected large-scale tree mortality in the United States, Atmos. Chem. Phys., 16, 2323-2340, doi:10.5194/acp-16-2323-2016, 2016.

Ginoux, P., Prospero, J. M., Gill, T. E., Hsu, N. C., and Zhao, M.: GLOBAL-SCALE ATTRIBUTION OF ANTHROPOGENIC AND NATURAL DUST SOURCES AND THEIR EMISSION RATES BASED ON MODIS DEEP BLUE AEROSOL PRODUCTS, Rev. Geophys., 50, RG3005, doi:10.1029/2012rg000388, 2012.

Guenther, A. B., Jiang, X., Heald, C. L., Sakulyanontvittaya, T., Duhl, T., Emmons, L. K., and Wang, X.: The Model of Emissions of Gases and Aerosols from Nature version 2.1 (MEGAN2.1): an extended and updated framework for modeling biogenic emissions, Geosci. Model Dev., 5, 1471-1492, doi:10.5194/gmd-51471-2012, 2012.

Hallquist, M., Wenger, J. C., Baltensperger, U., Rudich, Y., Simpson, D., Claeys, M., Dommen, J., Donahue, N. M., George, C., Goldstein, A. H., Hamilton, J. F., Herrmann, H., Hoffmann, T., Iinuma, Y., Jang, M., Jenkin, M. E., Jimenez, J. L., Kiendler-Scharr, A., Maenhaut, W., McFiggans, G., Mentel, Th. F., Monod, A., Prévôt, A. S. H., Seinfeld, J. H., Surratt, J. D., Szmigielski, R., and Wildt, J.: The formation, properties and impact of secondary organic aerosol: current and emerging issues, Atmos. Chem. Phys., 9, 5155-5236, doi:10.5194/acp-9-51552009, 2009.

Hansen, M. C., Potapov, P. V., Moore, R., Hancher, M., Turubanova, S. A., Tyukavina, A., Thau, D., Stehman, S. V., Goetz, S. J., Loveland, T. R., Kommareddy, A., Egorov, A., Chini, L., Justice, C. O., and Townshend, J. R. G.: High-Resolution Global Maps of 21st-Century Forest Cover Change, Science, 342, 850-853, 2013.

Hardacre, C., Wild, O., and Emberson, L.: An evaluation of ozone dry deposition in global scale chemistry climate models, Atmos. Chem. Phys., 15, 6419-6436, doi:10.5194/acp-15-64192015, 2015.

Heald, C. L. and Spracklen, D. V.: Land Use Change Impacts on Air Quality and Climate, Chem. Rev., 115, 4476-4496, 2015.

Heald, C. L., Henze, D. K., Horowitz, L. W., Feddema, J., Lamarque, J. F., Guenther, A., Hess, P. G., Vitt, F., Seinfeld, J. H., Goldstein, A. H., and Fung, I.: Predicted change in global secondary organic aerosol concentrations in response to future climate, emissions, and land use change, J. Geophys. Res.-Atmos., 113, D05211, doi:10.1029/2007JD009092, 2008.

Heald, C. L., Coe, H., Jimenez, J. L., Weber, R. J., Bahreini, R., Middlebrook, A. M., Russell, L. M., Jolleys, M., Fu, T.-M., Allan, J. D., Bower, K. N., Capes, G., Crosier, J., Morgan, W. T., Robinson, N. H., Williams, P. I., Cubison, M. J., DeCarlo, P. F., and Dunlea, E. J.: Exploring the vertical profile of atmospheric organic aerosol: comparing 17 aircraft field campaigns with a global model, Atmos. Chem. Phys., 11, 12673-12696, doi:10.5194/acp-11-12673-2011, 2011. 
Heald, C. L., Ridley, D. A., Kroll, J. H., Barrett, S. R. H., CadyPereira, K. E., Alvarado, M. J., and Holmes, C. D.: Contrasting the direct radiative effect and direct radiative forcing of aerosols, Atmos. Chem. Phys., 14, 5513-5527, doi:10.5194/acp-14-55132014, 2014.

Holmes, C. D., Prather, M. J., Søvde, O. A., and Myhre, G.: Future methane, hydroxyl, and their uncertainties: key climate and emission parameters for future predictions, Atmos. Chem. Phys., 13, 285-302, doi:10.5194/acp-13-285-2013, 2013.

Hudman, R. C., Moore, N. E., Mebust, A. K., Martin, R. V., Russell, A. R., Valin, L. C., and Cohen, R. C.: Steps towards a mechanistic model of global soil nitric oxide emissions: implementation and space based-constraints, Atmos. Chem. Phys., 12, 7779-7795, doi:10.5194/acp-12-7779-2012, 2012.

Hurtt, G. C., Frolking, S., Fearon, M. G., Moore, B., Shevliakova, E., Malyshev, S., Pacala, S. W., and Houghton, R. A.: The underpinnings of land-use history: three centuries of global gridded land-use transitions, wood-harvest activity, and resulting secondary lands, Glob. Change Biol., 12, 1208-1229, 2006.

Hurtt, G. C., Chini, L. P., Frolking, S., Betts, R. A., Feddema, J., Fischer, G., Fisk, J. P., Hibbard, K., Houghton, R. A., Janetos, A., Jones, C. D., Kindermann, G., Kinoshita, T., Goldewijk, K. K., Riahi, K., Shevliakova, E., Smith, S., Stehfest, E., Thomson, A., Thornton, P., van Vuuren, D. P., and Wang, Y. P.: Harmonization of land-use scenarios for the period 1500-2100: 600 years of global gridded annual land-use transitions, wood harvest, and resulting secondary lands, Climatic Change, 109, 117-161, 2011.

IPCC: Climate Change 2013: The Physical Science Basis. Contribution of Working Group I to the Fifth Assessment Report of the Intergovernmental Panel on Climate Change Cambridge, UK, 1535 pp., 2013.

Jaeglé, L., Quinn, P. K., Bates, T. S., Alexander, B., and Lin, J.-T.: Global distribution of sea salt aerosols: new constraints from in situ and remote sensing observations, Atmos. Chem. Phys., 11, 3137-3157, doi:10.5194/acp-11-3137-2011, 2011.

Lawrence, D. M., Oleson, K. W., Flanner, M. G., Thornton, P. E., Swenson, S. C., Lawrence, P. J., Zeng, X., Yang, Z.-L., Levis, S., Sakaguchi, K., Bonan, G. B., and Slater, A. G.: Parameterization Improvements and Functional and Structural Advances in Version 4 of the Community Land Model, J. Adv. Model. Earth Syst., 3, M03001, doi:10.1029/2011ms000045, 2011.

Lawrence, P. J., Feddema, J. J., Bonan, G. B., Meehl, G. A., O’Neill, B. C., Levis, S., Lawrence, D. M., Oleson, K. W., Kluzek, E., Lindsay, K., and Thorton, P. E.: Simulating the Biogeochemical and Biogeophysical Impacts of Transient Land Cover Change and Wood Harvest in the Community Climate System Model (CCSM4) from 1850 to 2100, J. Climate, 25, 3071-3095, 2012.

Lim, S. S., Vos, T., and Flaxman, A. D.: A comparative risk assessment of burden of disease and injury attributable to 67 risk factors and risk factor clusters in 21 regions, 1990-2010: a systematic analysis for the Global Burden of Disease Study 2010 (Vol. 380, p. 2224, 2012), Lancet, 381, 1276-1276, 2013.

Menon, S., Del Genio, A. D., Koch, D., and Tselioudis, G.: GCM Simulations of the aerosol indirect effect: Sensitivity to cloud parameterization and aerosol burden, J. Atmos. Sci., 59, 692713, 2002.

Myhre, G., Samset, B. H., Schulz, M., Balkanski, Y., Bauer, S., Berntsen, T. K., Bian, H., Bellouin, N., Chin, M., Diehl, T., Easter, R. C., Feichter, J., Ghan, S. J., Hauglustaine, D., Iversen,
T., Kinne, S., Kirkevåg, A., Lamarque, J.-F., Lin, G., Liu, X., Lund, M. T., Luo, G., Ma, X., van Noije, T., Penner, J. E., Rasch, P. J., Ruiz, A., Seland, Ø., Skeie, R. B., Stier, P., Takemura, T., Tsigaridis, K., Wang, P., Wang, Z., Xu, L., Yu, H., Yu, F., Yoon, J.-H., Zhang, K., Zhang, H., and Zhou, C.: Radiative forcing of the direct aerosol effect from AeroCom Phase II simulations, Atmos. Chem. Phys., 13, 1853-1877, doi:10.5194/acp-13-18532013, 2013.

OECD: OECD Environmental Outlook to 2050: The Consequences of Inaction, OECD Publishing, 2012.

Park, R. J., Jacob, D. J., Chin, M., and Martin, R. V.: Sources of carbonaceous aerosols over the United States and implications for natural visibility, J. Geophys. Res.-Atmos., 108, 4355, doi:10.1029/2002JD003190, 2003.

Paulot, F., Ginoux, P., Cooke, W. F., Donner, L. J., Fan, S., Lin, M.Y., Mao, J., Naik, V., and Horowitz, L. W.: Sensitivity of nitrate aerosols to ammonia emissions and to nitrate chemistry: implications for present and future nitrate optical depth, Atmos. Chem. Phys., 16, 1459-1477, doi:10.5194/acp-16-1459-2016, 2016.

Pielke, R. A., Marland, G., Betts, R. A., Chase, T. N., Eastman, J. L., Niles, J. O., Niyogi, D. D. S., and Running, S. W.: The influence of land-use change and landscape dynamics on the climate system: relevance to climate-change policy beyond the radiative effect of greenhouse gases, Philos. T. R. Soc. Lond. A, 360, 1705-1719, 2002.

Pielke, R. A., Pitman, A., Niyogi, D., Mahmood, R., McAlpine, C., Hossain, F., Goldewijk, K. K., Nair, U., Betts, R., Fall, S., Reichstein, M., Kabat, P., and de Noblet, N.: Land use/land cover changes and climate: modeling analysis and observational evidence, Wiley Interdiscip. Rev.-Clim. Chang., 2, 828-850, 2011.

Pinder, R. W., Adams, P. J., and Pandis, S. N.: Ammonia emission controls as a cost-effective strategy for reducing atmospheric particulate matter in the eastern United States, Environ. Sci. Technol., 41, 380-386, 2007.

Pitman, A. J., de Noblet-Ducoudre, N., Cruz, F. T., Davin, E. L., Bonan, G. B., Brovkin, V., Claussen, M., Delire, C., Ganzeveld, L., Gayler, V., van den Hurk, B., Lawrence, P. J., van der Molen, M. K., Muller, C., Reick, C. H., Seneviratne, S. I., Strengers, B. J., and Voldoire, A.: Uncertainties in climate responses to past land cover change: First results from the LUCID intercomparison study, Geophys. Res. Lett., 36, L14814, doi:10.1029/2009g1039076, 2009.

Pye, H. O. T. and Seinfeld, J. H.: A global perspective on aerosol from low-volatility organic compounds, Atmos. Chem. Phys., 10, 4377-4401, doi:10.5194/acp-10-4377-2010, 2010.

Pye, H. O. T., Liao, H., Wu, S., Mickley, L. J., Jacob, D. J., Henze, D. K., and Seinfeld, J. H.: Effect of changes in climate and emissions on future sulfate-nitrate-ammonium aerosol levels in the United States, J. Geophys. Res.-Atmos., 114, D01205, doi:10.1029/2008jd010701, 2009.

Pye, H. O. T., Chan, A. W. H., Barkley, M. P., and Seinfeld, J. H.: Global modeling of organic aerosol: the importance of reactive nitrogen $\left(\mathrm{NO}_{x}\right.$ and $\left.\mathrm{NO}_{3}\right)$, Atmos. Chem. Phys., 10, 1126111276, doi:10.5194/acp-10-11261-2010, 2010.

Ridley, D. A., Heald, C. L., Pierce, J. R., and Evans, M. J.: Towards resolution-indepdent dust emissions in global models, Geophys. Res. Lett., 40, 2873-2877, 2013.

Shindell, D., Kuylenstierna, J. C. I., Vignati, E., van Dingenen, R., Amann, M., Klimont, Z., Anenberg, S. C., Muller, N., Janssens- 
Maenhout, G., Raes, F., Schwartz, J., Faluvegi, G., Pozzoli, L., Kupiainen, K., Hoglund-Isaksson, L., Emberson, L., Streets, D., Ramanathan, V., Hicks, K., Oanh, N. T. K., Milly, G., Williams, M., Demkine, V., and Fowler, D.: Simultaneously Mitigating Near-Term Climate Change and Improving Human Health and Food Security, Science, 335, 183-189, 2012.

Smith, S. J. and Bond, T. C.: Two hundred fifty years of aerosols and climate: the end of the age of aerosols, Atmos. Chem. Phys., 14, 537-549, doi:10.5194/acp-14-537-2014, 2014.

Stevenson, D. S., Dentener, F. J., Schultz, M. G., Ellingsen, K., van Noije, T. P. C., Wild, O., Zeng, G., Amann, M., Atherton, C. S., Bell, N., Bergmann, D. J., Bey, I., Butler, T., Cofala, J., Collins, W. J., Derwent, R. G., Doherty, R. M., Drevet, J., Eskes, H. J., Fiore, A. M., Gauss, M., Hauglustaine, D. A., Horowitz, L. W., Isaksen, I. S. A., Krol, M. C., Lamarque, J. F., Lawrence, M. G., Montanaro, V., Muller, J. F., Pitari, G., Prather, M. J., Pyle, J. A., Rast, S., Rodriguez, J. M., Sanderson, M. G., Savage, N. H., Shindell, D. T., Strahan, S. E., Sudo, K., and Szopa, S.: Multimodel ensemble simulations of present-day and near-future tropospheric ozone, J. Geophys. Res.-Atmos., 111, D08301, doi:10.1029/2005jd006338, 2006.

Stevenson, D. S., Young, P. J., Naik, V., Lamarque, J.-F., Shindell, D. T., Voulgarakis, A., Skeie, R. B., Dalsoren, S. B., Myhre, G., Berntsen, T. K., Folberth, G. A., Rumbold, S. T., Collins, W. J., MacKenzie, I. A., Doherty, R. M., Zeng, G., van Noije, T. P. C., Strunk, A., Bergmann, D., Cameron-Smith, P., Plummer, D. A., Strode, S. A., Horowitz, L., Lee, Y. H., Szopa, S., Sudo, K., Nagashima, T., Josse, B., Cionni, I., Righi, M., Eyring, V., Conley, A., Bowman, K. W., Wild, O., and Archibald, A.: Tropospheric ozone changes, radiative forcing and attribution to emissions in the Atmospheric Chemistry and Climate Model Intercomparison Project (ACCMIP), Atmos. Chem. Phys., 13, 3063-3085, doi:10.5194/acp-13-3063-2013, 2013.

Tai, A. P. K., Mickley, L. J., and Jacob, D. J.: Impact of 2000-2050 climate change on fine particulate matter $\left(\mathrm{PM}_{2.5}\right)$ air quality inferred from a multi-model analysis of meteorological modes, Atmos. Chem. Phys., 12, 11329-11337, doi:10.5194/acp-1211329-2012, 2012.

Tai, P. K., Mickley, L. J., Wu, S., and Heald, C. L.: Effect of $\mathrm{CO}_{2}$ inhibition on biogenic isoprene emission: implications for air quality under 2000-to-2050 changes in climate, vegetation and land use, Geophys. Res. Lett., 40, 3479-3483, 2013.

Unger, N.: Human land-use-driven reduction of forest volatiles cools global climate, Nat. Clim. Chang., 4, 907-910, 2014.

van der Werf, G. R., Randerson, J. T., Giglio, L., Collatz, G. J., Mu, M., Kasibhatla, P. S., Morton, D. C., DeFries, R. S., Jin, Y., and van Leeuwen, T. T.: Global fire emissions and the contribution of deforestation, savanna, forest, agricultural, and peat fires (19972009), Atmos. Chem. Phys., 10, 11707-11735, doi:10.5194/acp10-11707-2010, 2010. van Vuuren, D. P., Edmonds, J., Kainuma, M., Riahi, K., Thomson, A., Hibbard, K., Hurtt, G. C., Kram, T., Krey, V., Lamarque, J. F., Masui, T., Meinshausen, M., Nakicenovic, N., Smith, S. J., and Rose, S. K.: The representative concentration pathways: an overview, Climatic Change, 109, 5-31, 2011.

Verbeke, T., Lathière, J., Szopa, S., and de Noblet-Ducoudré, N.: Impact of future land-cover changes on $\mathrm{HNO}_{3}$ and $\mathrm{O}_{3}$ surface dry deposition, Atmos. Chem. Phys., 15, 13555-13568, doi:10.5194/acp-15-13555-2015, 2015.

Vitousek, P. M., Mooney, H. A., Lubchenco, J., and Melillo, J. M.: Human domination of Earth's ecosystems, Science, 277, 494 499, 1997.

Wang, K. Y. and Shallcross, D. E.: Modelling terrestrial biogenic isoprene fluxes and their potential impact on global chemical species using a coupled LSM-CTM model, Atmos. Environ., 34, 2909-2925, 2000.

Ward, D. S., Mahowald, N. M., and Kloster, S.: Potential climate forcing of land use and land cover change, Atmos. Chem. Phys., 14, 12701-12724, doi:10.5194/acp-14-12701-2014, 2014.

Wesely, M. L.: Parameterization of surface resistances to gaseous dry deposition in regional scale numerical models, Atmos. Environ., 23, 1293-1304, 1989.

Wesely, M. L. and Hicks, B. B.: A review of the current status of knowledge on dry deposition, Atmos. Environ., 34, 2261-2282, 2000.

Wu, S., Mickley, L. J., Kaplan, J. O., and Jacob, D. J.: Impacts of changes in land use and land cover on atmospheric chemistry and air quality over the 21 st century, Atmos. Chem. Phys., 12, $1597-$ 1609, doi:10.5194/acp-12-1597-2012, 2012.

Wu, S. L., Mickley, L. J., Leibensperger, E. M., Jacob, D. J., Rind, D., and Streets, D. G.: Effects of 2000-2050 global change on ozone air quality in the United States, J. Geophys. Res.-Atmos., 113, D06302, doi:10.1029/2007jd008917, 2008.

Young, P. J., Archibald, A. T., Bowman, K. W., Lamarque, J.-F., Naik, V., Stevenson, D. S., Tilmes, S., Voulgarakis, A., Wild, O., Bergmann, D., Cameron-Smith, P., Cionni, I., Collins, W. J., Dalsøren, S. B., Doherty, R. M., Eyring, V., Faluvegi, G., Horowitz, L. W., Josse, B., Lee, Y. H., MacKenzie, I. A., Nagashima, T., Plummer, D. A., Righi, M., Rumbold, S. T., Skeie, R. B., Shindell, D. T., Strode, S. A., Sudo, K., Szopa, S., and Zeng, G.: Preindustrial to end 21st century projections of tropospheric ozone from the Atmospheric Chemistry and Climate Model Intercomparison Project (ACCMIP), Atmos. Chem. Phys., 13, 20632090, doi:10.5194/acp-13-2063-2013, 2013.

Zhang, L. M., Gong, S. L., Padro, J., and Barrie, L.: A sizesegregated particle dry deposition scheme for an atmospheric aerosol module, Atmos. Environ., 35, 549-560, 2001. 